dr Veljko DELIBAŠI $\check{C}^{*}$

Advokat iz Beograda

naučni saradnik
Pregledni naučni rad

UDK: 343.261(497.11)

Primeljeno: 17. februar 2021.

Prihvaćeno: 10. mart 2021.

https://doi: $10.47152 /$ rkkp.59.1.4

\title{
KAZNA DOŽIVOTNOG ZATVORA BEZ PRAVA NA USLOVNI OTPUST
}

U uvodnom delu rada ukazano je na dileme koje postoje u vezi sa kaznom doživotnog zatvora, a zatim se definiše pojam kazne i određuje svrha kažnjavanja, uz navođenje osnovnih karakteristika kazne doživotnog zatvora. Posebna pažnja je posvećena kazni doživotnog zatvora kod krivičnih dela kod kojih nije moguć uslovni otpust, uz ukazivanje na propuste zakonodavca uz sugestiju kako bi uočeni propusti mogli da se isprave. Obrađen je institut uslovnog otpusta, Evropska konvencija za zaštitu ljudskih prava i osnovnih sloboda u kontekstu kazne doživotnog zatvora, a zatim je dat kritički osvrt na zaključke Ekspertskog sastanka održanog u Beogradu 25. septembra 2020. godine. Tu se daje objašnjenje zašto nije potrebno menjati postojeće rešenje u našem krivičnom zakonodavstvu, uz napomenu da čak $i$ kada bi se prihvatio stav iz tih zaključaka, da treba promeniti postojeće rešenje, u radu se ističe da način na koji se predlaže da se to uradi nije prihvatljiv jer se cilj (za koji se autor ovog rada ne zalaže) ne bi postigao predlozima iz tog zaključka. Inače, cilj rada je bio da se pronađu kvalitetni argumenti za postojeće rešenje u našem krivičnom zakonodavstvu, po kome za pojedina krivična dela ili najteže oblike teških krivičnih dela može da se izrekne kazna doživotnog zatvora bez prava na uslovni otpust. Takođe, cilj je bio 
i da se ukaže da zaključci Ekspertskog sastanka održanog u Beogradu 25. septembra 2020, a naročito predlozi sadržani u tim zaključcima nisu prihvatljivi kada je reč o našem krivičnom zakonodavstvu.

\section{Ključne reči: kazna, doživotni zatvor, uslovni otpust, ljudska prava, krivično pravo.}

\section{Uvod}

Od ukidanja smrtne kazne do danas polemiše se u naučnoj, stručnoj i opštoj javnosti, koja je to kazna koja bi adekvatno zamenila ukinutu smrtnu kaznu. Tako se nailazi na ideje da to bude kazna zatvora od 40 godina, kazna zatvora od 30 do 40 godina, dugotrajni zatvor ili doživotni zatvor. S obzirom na to da se naš zakonodavac, nakon kazne zatvora od 40 godina, odnosno kazne zatvora od 30 do 40 godine, u decembru 2019. opredelio za doživotni zatvor, polemika je nastavljena ali ovog puta na temu da li je prihvatljiva kazna doživotnog zatvora bez prava na uslovni otpust, uopšte ili kod pojedinih krivičnih dela. Naravno, postoji i čitav niz drugih spornih pitanja koja se odnose na doživotni zatvor, počev od toga kojim licima se može, odnosno ne može izreći kazna doživotnog zatvora, za koja dela ili teške oblike kojih dela je to moguće, u kakvim uslovima treba da se izdržava kazna doživotnog zatvora, da li je maksimum kazne zatvora od 20 godina uz doživotni zatvor adekvatan maksimum kazne zatvora, pa sve do toga da li se na lica koja su osuđena na ovu kaznu mogu odnositi bilo kakve privilegije, pored već spornog uslovnog otpusta, pre svega amnestija i pomilovanje. Svakako, najspornije pitanje je da li kazna doživotnog zatvora bez prava na uslovni otpust kod pojedinih krivičnih dela sme da egzistira u krivičnom pravu naše zemlje, odnosno da li je to u skladu sa Evropskom konvencijom za zaštitu ljudskih prava i osnovnih sloboda i odlukama Evropskog suda za ljudska prava u Strazburu.

\section{Pojam kazne i svrha kažnjavanja}

Kaznom se učinilac krivičnog dela lišava određenih dobara. Ta dobra moraju biti dovoljno značajna (život, sloboda, imovina) da bi učinilac krivičnog dela i potencijalni učinioci shvatili u kojoj meri društvo osuđuje krivično delo koje je učinjeno (Ignjatović, 2000: 251). Kazna se definiše kao "zakonom predviđena represivna mera koja se s ciljem suzbijanja kriminaliteta primenjuje prema učiniocu krivičnog dela na osnovu odluke suda nakon sprovedenog krivičnog postupka” (Stojanović, Škulić, Delibašić, 2018: 110). 
Postoje tri teorije koje određuju svrhu kažnjavanja, apsolutna, relativna i mešovita. Kod apsolutne teorije kazna je odmazda za učinjeno delo, tj. svrha kazne je vraćanje zla za učinjeno zlo, relativna teorija svrhu kazne vidi u prevenciji, koja može biti generalna ili specijalna, dok mešovita teorija smatra da je svrha kazne i retribucija i prevencija (Stojanović, Škulić, Delibašić, 2018: 110-111). Krivični zakonik polazi od mešovite teorije i precizira da je opšta svrha propisivanja i izricanja svih krivičnih sankcija suzbijanje dela kojima se povređuju ili ugrožavaju vrednosti zaštićene krivičnim zakonodavstvom (član 4 stav $2 \mathrm{KZ}$ ), kao i da je, u okviru opšte svrhe krivičnih sankcija, svrha kažnjavanja: 1) sprečavanje učinioca da čini krivična dela i uticanje na njega da ubuduće ne čini krivična dela; 2) uticanje na druge da ne čine krivična dela; 3 ) izražavanje društvene osude za krivično delo, jačanje morala i učvršćivanje obaveze poštovanja zakona; 4) ostvarivanje pravednosti i srazmernosti između učinjenog dela i težine krivične sankcije (član $42 \mathrm{KZ}$ ).

Kada je reč o retributivnoj svrsi kažnjavanja, treba imati u vidu da je ostvarivanje pravednosti i srazmernosti učinjenog dela i težine krivične sankcije, što predstavlja svojvrsni vid retribucije, kao svrhe kažnjavanja, propisano kada je uvedena i kazna doživotnog zatvora. ${ }^{1}$ Ideja da se prihvati filozofija retribucije, kod našeg zakonodavca, koja počiva na uverenju da kazna mora biti osveta za štetu nanesenu drugima, u skladu je sa stavom i uverenjem javnosti i političkih struktura mnogih zemalja, gde je to, kao i kod nas, poslednjih decenija, postalo vladajuće shvatanje, uz sve manju orjentisanost na rehabilitaciju (Stevanović, 2016: 429).

Takođe, u poslednje vreme sve češće se ističe da su retribucija i zastrašivanje sastavni delovi kazne i da se to ne može, ne sme i ne treba negirati. Država treba i mora da kažnjava adekvatnim kaznama učinioce krivičnih dela, jer je ona garant bezbednosti svih građana. Negiranjem potrebe za pravednom odmazdom, praktično se abolira učinjeno, a zločincu se pristupa kao da je reč o bolesniku kojeg treba lečiti (Dragojlović, Bingulac, 2019: 71), što nije prihvatljivo kada je reč o učiniocu krivičnog dela, koje u svom opštem pojmu sadrži i krivicu.

\section{Kazna doživotnog zatvora}

Za razliku od prethodnog zakonskog rešenja koje je poznavalo četiri vrste kazni, sadašnje rešenje propisuje pet vrsti kazni: 1) doživotni zatvor; 2) kaznu zatvora; 3) novčanu kaznu; 4) rad u javnom interesu; i 5) oduzimanje vozačke dozvole (član $43 \mathrm{KZ}$ ). Mada bi se i za prethodno zakonsko rešenje moglo tvrditi da je postojalo pet vrsti kazni, s obzirom na to da je kazna zatvora od 30 do 40 godina

1 “Službeni glasnik RS”, broj 35/19. 
predstavljala više posebnu vrstu kazne zatvora, nego izuzetak od opšteg maksimuma kazne zatvora, sada nema nikakve dileme da kazna doživotnog zatvora predstavlja posebnu vrstu kazne.

Za najteža krivična dela i najteže oblike teških krivičnih dela može se uz kaznu zatvora izuzetno propisati i kazna doživotnog zatvora. Kada je reč o izricanju ove kazne, postoje ograničenja, jer se ona ne može izreći licu koje u vreme izvršenja krivičnog dela nije navršilo dvadeset jednu godinu života. Takođe, ne može se izreći u slučajevima kada zakon predviđa da se kazna može ublažiti (član 56. stav 1. tačka 1) ili kada postoji neki od osnova za oslobođenje od kazne (član 44a KZ). Zakonodavac potencira da se kazna doživotnog zatvora može propisati samo izuzetno, a, uz to, teleološkim tumačenjem dolazi se do toga da taj izuzetni karakter doživotne kazne zatvora važi i za njeno izricanje (Stojanović, 2020: 233).

Kao što i sam naziv ove kazne govori, kod nje osuđeni ostaje u zatvoru do kraja života. Naravno, od ovoga pravila postoje odstupanja koja se ogledaju pre svega u mogućnosti primene nekog od tri instituta: uslovnog otpusta, amnestije ili pomilovanja.

\section{Doživotni zatvor kod krivičnih dela kod kojih nije moguć uslovni otpust}

Prema Krivičnom zakoniku postoji pet krivičnih dela kod kojih sud ne može uslovno otpustiti osuđenog, bez obzira na to na koju kaznu su osuđeni. To su: teško ubistvo iz člana 114 stav 1 tačka 9 , silovanje iz člana 178 stav 4, obljuba nad nemoćnim licem iz člana 179 stav 3, obljuba sa detetom iz člana 180 stav 3 i obljuba zloupotrebom položaja iz člana 181 stav 5 Krivičnog zakonika, a za svih pet krivičnih dela pored kazne zatvora, propisana je i kazna doživotnog zatvora. Ovde se odmah postavljaju dva pitanja, na koje ne može da se da odgovor koji bi se branio valjanim argumentima. Naime, zbog čega je takvo ograničenje dato baš za ova krivična dela i zbog čega takvo ograničenje ne postoji kod krivičih dela koja su nesporno teža od ovih (pre svega po posledici koju prouzrokuju), na primer, genocid, ratni zločini ili agresivni rat. ${ }^{2}$

2 Laička javnost često ne shvata koja su krivična dela objektivno teža. Tako se svojevremeno novinarka obratila autoru ovog teksta za objašnjenje u vezi sa propisanom kaznom za pojedina krivična dela, pa je na kritički osvrt autora, rekla da je za nju daleko teže kad neko siluje ili ubije dvogodišnje dete nego kad izvrši genocid ili ratni zločin (!?). Nakon objašnjenja da, na primer, genocid ili ratni zločin protiv civilnog stanovništva može da sadrži stotine, pa čak i hiljade silovane ili ubijene dece, obećala je da će korigovati stavove koje iznosi u novinama za koje piše. 
Pored toga, treba reći da jedino kod teškog ubistva (član 114 stav 1 tačka 9) nije sporan način na koji je propisana kazna doživotnog zatvora jer je za postojanje tog krivičnog dela, pored umišljajne radnje ubistva, potrebno da uzrast pasivnog subjekta (dete), odnosno stanje pasivnog subjekta (bremenita žena) budu takođe obuhvaćeni umišljajem učinioca. U suprotnom, ako ove kvalifikatorne okolnosti ne bi bile obuhvaćene umišljajem učinioca, ne bi se radilo o teškom već o običnom ubistvu iz člana 113 Krivičnog zakonika.

Međutim, kod ostala četiri krivična dela, ukoliko prihvatimo da je propisivanje kazne doživotnog zatvora opravdano, ${ }^{3}$ postoji problem ukoliko je reč o smrtnoj posledici pasivnog subjekta kao kvalifikatornoj okolnosti. Naime, za postojanje najtežeg oblika nekog od ovih krivičnih dela, a samim tim i mogućnosti da se izrekne kazna doživotnog zatvora, potrebno je da je smrtna posledica obuhvaćena nehatom učinioca. U suprotnom, ako je smrt obuhvaćena umišljajem učinioca, na osnovu izričite odredbe člana 27 Krivičnog zakonika, radilo bi se o sticaju osnovnog oblika krivičnog dela i krivičnog dela ubistvo iz člana 113 Krivičnog zakonika, a to dalje znači da jedinstvena kazna ne bi mogla da bude doživotni zatvor. Naime, u tom slučaju jedinstvena kazna zatvora bi se kretala u rasponu od deset godina i jednog meseca do dvadeset godina zatvora. Ovakvo rešenje se može argumentovano kritikovati.

Rešenje tog problema bi bilo da se propiše još jedan oblik teškog ubistva, koji bi činio onaj ko drugog liši života prilikom izvršenja silovanja, obljube nad nemoćnim licem, obljube sa detetom ili obljube zloupotrebom položaja (Stojanović, 2020: 585). Tada bi i u tom slučaju (smrtna posledica obuhvaćena umišljajem izvršioca) mogla da se izrekne kazna doživotnog zatvora. Kada je kod ovih krivičnih dela reč o kvalifikatornoj okolnosti koja se ogleda u uzrastu pasivnog subjekta, tj. da je reč o detetu, nije sporno da ta okolnost mora biti obuhvaćena umišljajem učinioca. U suprotnom, ne bi se radilo o najtežem već o nekom drugom obliku krivičnog dela, pa ne bi ni mogla da se izrekne kazna doživotnog zatvora.

\section{Uslovni otpust}

Osuđenog koji je izdržao dve trećine kazne zatvora sud će uslovno otpustiti sa izdržavanja kazne, ako se u toku izdržavanja kazne tako popravio da se može sa osnovom očekivati da će se na slobodi dobro vladati, a naročito da do isteka vremena za koje je izrečena kazna ne učini novo krivično delo. Pri oceni

3 Kod ovih krivičnih dela do smrtne posledice dolazi usled nehata, pa se samim tim postavlja pitanje da li je neophodno propisati najstrožu kaznu. Propisivanje kazne doživotnog zatvora za ova dela se po pravilu u literaturi kritikuje, upravo zbog činjenice da se ne radi o umišljajnom lišenju života. 
da li će se osuđeni uslovno otpustiti uzeće se u obzir njegovo vladanje za vreme izdržavanja kazne, izvršavanje radnih obaveza, s obzirom na njegovu radnu sposobnost, kao i druge okolnosti koje ukazuju da osuđeni dok traje uslovni otpust neće izvršiti novo krivično delo. Ne može se uslovno otpustiti osuđeni koji je tokom izdržavanja kazne dva puta kažnjavan za teže disciplinske prestupe i kome su oduzete dodeljene pogodnosti (član 46 stav $1 \mathrm{KZ}$ ). Ukoliko ispunjava ove uslove, sud može uslovno otpustiti osuđenog koji je osuđen na kaznu doživotnog zatvora, ako je izdržao dvadeset sedam godina (član 46 stav $2 \mathrm{KZ}$ ), ali ne može uslovno otpustiti osuđenog za krivična dela: teško ubistvo (član 114. stav 1. tačka 9), silovanje (član 178. stav 4), obljuba nad nemoćnim licem (179. stav 3), obljuba sa detetom (član 180. stav 3) i obljuba zloupotrebom položaja (član 181. stav 5), bez obzira na to na koju kaznu je osuđen (član 46 stav $5 \mathrm{KZ}$ ).

Suština uslovnog otpusta je u tome da se deo kazne ne izvršava, tako da se ne može prihvatiti shvatanje da je uslovni otpust samo faza u izvršenju kazne zatvora, odnosno da se kazna zatvora izvršava i za vreme dok je uslovno otpušteni na slobodi. Najbolji pokazatelj za to je činjenica da se ukoliko dođe do opoziva uslovnog otpusta, vreme koje je osuđeni proveo na uslovnom otpustu ne uračunava u izdržanu kaznu (Stojanović, 2010: 258). Kada se govori o uslovnom otpustu, po pravilu se ne potencira da on ima komponentu praštanja učiniocu krivičnog dela, jer mu se kazna smanjuje. Upravo je ta komponenta sporna sa stanovišta širih društvenih interesa i oštećenog krivičnim delom, pa se to uvek mora imati u vidu kada se analizira ustanova uslovnog otpusta (Škulić, 2016: 365).

Kada je reč o uslovnom otpustu, treba imati u vidu i rešenja iz Zakona o posebnim merama za sprečavanje vršenja krivičnih dela protiv polne slobode prema maloletnim licima ${ }^{4}$ (tzv. Marijin zakon). Ovim zakonom propisuju se posebne mere koje se sprovode prema učiniocima krivičnih dela protiv polne slobode izvršenih prema maloletnim licima (lica mlađa od 18 godina), a sam zakon se primenjuje na učinioce koji su prema maloletnim licima izvršili sledeća krivična dela: 1) silovanje (član 178. st. 3. i 4. KZ); 2) obljuba nad nemoćnim licem (član 179. st. 2. i 3. KZ); 3) obljuba sa detetom (član 180. KZ); 4) obljuba zloupotrebom položaja (član 181. KZ); 5) nedozvoljene polne radnje (član 182. KZ); 6) podvođenje i omogućavanje vršenja polnog odnosa (član 183. KZ); 7) posredovanje u vršenju prostitucije (član 184. stav 2. KZ); 8) prikazivanje, pribavljanje i posedovanje pornografskog materijala i iskorišćavanje maloletnog lica za pornografiju (član 185. KZ); 9) navođenje maloletnog lica na prisustvovanje polnim radnjama (član 185a KZ); 10) iskorišćavanje računarske mreže ili komunikacije 
drugim tehničkim sredstvima za izvršenje krivičnih dela protiv polne slobode prema maloletnom licu (član 185b KZ).

Ovaj zakon (član 5), pored toga što zabranjuje ublažavanje kazne učiniocu krivičnog dela obuhvaćenog ovim zakonom, odnosno pored toga što isključuje institut zasterelosti krivičnog gonjenja i izvršenja kazne za ova dela, eksplicitno propisuje da se lice osuđeno na kaznu zatvora za krivično delo na koje se odnosi ovaj zakon ne može uslovno otpustiti (stav 2). Dakle, znatno pre decembra 2019, kada su izvršene izmene Krivičnog zakonika, bila je propisana zabrana uslovnog otpuštanja osuđenih lica, između ostalih i za krivična dela silovanje (član 178. st. 3. i 4. KZ); 2) obljuba nad nemoćnim licem (član 179. st. 2. i 3. KZ); 3) obljuba sa detetom (član 180. KZ); 4) obljuba zloupotrebom položaja (član 181. KZ), ${ }^{5}$ pa je takvo propisivanje Krivičnim zakonikom iz 2019. nepotrebno, odnosno, nema potrebe u dva zakona propisivati istu zabranu.

\section{Evropska konvencija za zaštitu ljudskih prava i osnovnih sloboda i kazna doživotnog zatvora}

Evropska konvencija za zaštitu ljudskih prava i osnovnih sloboda propisuje (član 3) zabranu mučenja, odnosno da niko ne sme biti podvrgnut mučenju, ili nečovečnom ili ponižavajućem postupanju ili kažnjavanju. S tim u vezi, postavlja se pitanje da li je kazna doživotnog zatvora bez prava na uslovni otpust nečovečno kažnjavanje. Razmatrajući predstavku trojice osuđenika (Case of Vinter and Others v. The United Kigdom, 9 July 2013), Evropski sud za ljudska prava u Strazburu je zauzeo stav da je kazna doživotnog zatvora u suprotnosti sa članom 3 Evropske konvencije za zaštitu ljudskih prava i osnovnih sloboda ako takva kazna ne ostavlja mogućnost da se osuđeni po utvrđenoj zakonskoj proceduri posle izvesnog vremena nađe na slobodi (Đokić, 2016: 229-230).

Imajući u vidu ovakav stav suda, postavlja se pitanje da li je trenutno važeće rešenje u Krivičnom zakoniku saglasno sa Evropskom konvencijom za zaštitu ljudskih prava i osnovnih sloboda i stavom koji zastupa Evropski sud za ljudska prava u Strazburu. Uz napomenu da sam stav ovog suda nije nesporan, odnosno uz činjenicu da sudije Evropskog suda za ljudska prava nisu nepogrešivi ljudi, odnosno da i oni mogu po pojedinim pitanjima zauzeti pogrešan stav, što podrazumeva potrebu da isprave svoju grešku, treba reći da u našem pravnom sistemu,

5 Krivični zakonik iz decembra 2019. propisuje zabranu uslovnog otpusta i za lica koja su osuđena za krivično delo teško ubistvo iz člana 114 stav 1 tačka 9 Krivičnog zakonika. 
pored uslovnog otpusta postoje i druge mogućnosti da se osuđeno lice, pa i ono koje je osuđeno na doživotni zatvor, nađe na slobodi iako nije izdržalo kaznu na koju je osuđeno. To su pre svega amnestija i pomilovanje, ali i vanredni pravni lekovi, zahtev za ponavljanje krivičnog postupka i zahtev za zaštitu zakonitosti.

Kada je reč o licima koja su osuđena na kaznu doživotnog zatvora, za dela za koja nije moguće da budu uslovno otpuštena, u svetlu odluke Evropskog suda za ljudska prava koja je navedena, posebno je značajan zahtev za ponavljanje krivičnog postupka, koji pored ostalih razloga za ponavljanje postupka propisuje i slučaj ako se iznesu nove činjenice ili podnesu novi dokazi kojih nije bilo kada je izricana kazna zatvora ili sud za njih nije znao iako su postojali, a oni bi očigledno doveli do blaže krivične sankcije (član 473 stav 1 tačka 6 ZKP). Imajući u vidu da se pod pojmom "nove činjenice" mogu smatrati i penološki razlozi, koje zagovornici uslovnog otpusta potenciraju i ističu u prvi plan, kada zagovaraju mogućnost uslovog otpusta kod kazne doživotnog zatvora, može se konstatovati da se ta ideja može ostvarivati i kroz ovaj vanredni pravni lek. S obzirom na to da se procedura postupanja po ovom vanrednom pravnom leku precizno reguliše Zakonikom o krivičnom postupku (čl. 470-481), odnosno da je "ostavljena mogućnost da se osuđeni po utvrđenoj zakonskoj proceduri posle izvesnog vremena nađe na slobodi”, nema razloga ne tvrditi da je upravo zahvaljujući ovom vanrednom pravnom leku ispunjen zahtev koji u navedenoj presudi postavlja Evropski sud za ljudska prava u Strazburu.

\section{Kritički osvrt na zaključke Ekspertskog sastanka održanog u Beogradu 25. septembra 2020. godine}

Učesnici Ekspertskog sastanka (predstavnici krivičnopravne teorije i prakse Srbije, Slovenije, Hrvatske, BiH, Crne Gore i Makedonije) održanog u Beogradu 25. septembra 2020, u organizaciji Srpskog udruženja za krivičnopravnu teoriju i praksu i Instituta za kriminološka i sociološka istraživanja, na temu „Kazna doživotnog zatvora i međunarodni pravni standardi”, usvojili su sledeće zaključke:? 1. Predviđanje kazne doživotnog zatvora u nacionalnom krivičnom zakonodavstvu načelno nije u suprotnosti sa članom 3 Evropske konvencije o zaštiti ljudskih prava i osnovnih sloboda, ni praksom Evropskog suda za ljudska prava; 2. Prema relevantnim međunarodnim pravnim standardima i praksom ESLjP države u čijem krivičnom zakondavstvu je predviđena kazna doživotnog zatvora treba da predvide

7 Autor ovog teksta nije podržao donete zaključke i glasao je protiv njihovog usvajanja. 
instrumente kojima se pruža mogućnost svakom licu osuđenom na kaznu doživotnog zatvora da bude pušteno na slobodu posle određenog vremena provedenog u kazneno-popravnoj ustanovi i ispunjenja drugih zakonom predviđenih uslova, unapred poznatih osuđenom licu i zasnovanih na penološkim razlozima, o čijoj se ispunjenosti odlučuje u pravičnom postupku; 3 . U važećem tekstu Krivičnog zakonika nisu predviđeni krivičnoporavni instrumenti koji bi dali mogućnost svakom licu osuđenom na kaznu doživotnog zatvora za sva dela za koja se ona može izreći (odnosno pojedine njihove oblike), da, ispunjenjem određenih zakonom predviđenih uslova, bude pušteno na slobodu posle određenog vremena provedenog $\mathrm{u}$ ustanovi za izvršenje krivičnih sankcija; 4. Učesnici Ekspertskog sastanka su saglasni sa stavom iznetim u Izveštaju eksperta prof. dr Vida Jakulina da su dva moguća načina za usaglašavanje odredaba Krivičnog zakonika o kazni doživotnog zatvora sa mađunarodnim pravnim standaradima, članom 3 Evropske konvencije o zaštiti ljudskih prava i osnovnih sloboda i sudskom praksom ESLjP po ovom pitanju, i to: a) Izmene i dopune Krivičnog zakonika s ciljem davanja mogućnosti svakom licu osuđenom na kaznu doživotnog zatvora da pokrene postupak puštanja na uslovni otpust nakon isteka vremena utvrđenog u Krivičnom zakoniku, i preciziranje objektivnih kriterijuma i odgovarajućih proceduralnih garancija za adekvatno donošenja odluke po podnesenoj molbi, uslova pod kojima se osuđeno lice pušta na uslovni otpust i posledica nepoštovanja uslova pod kojima je pušten na uslovni otpust; b) Zadržati postojeće odredbe Krivičnog zakonika o kazni doživotnog zatvora ali izvršiti izmene i dopune Zakonika o krivičnom postupku s ciljem uvođenja novog - posebnog vanrednog pravnog leka - Zahteva za vanredno ublažavanje kazne kao procesnog mehanizma koji omogućava naknadno preispitivanje izrečene kazne doživotnog zatvora, u kojem bi kao jedan od osnova za mogućnost njegovog ulaganja bio i penološki razlog, odnosno već postignuta svrha kažnjavanja u toku izdržavanja izrečene kazne doživotnog zatvora - uz konkretizaciju i drugih pitanja ovog vanrednog pravnog leka (npr. nemogućnost podnošenja zahteva po osnovu procene o već postignutoj svrsi kažnjava pre dvadeset i pet godina izdržane kazne doživotnog zatvora).

Na ovom mestu prvo treba reći da važeće rešenje u krivičnom zakonodavstvu nije u suprotnosti sa međunarodnim pravnim standardima, pa samim tim nije ni potrebno da se bilo šta menja radi usaglašavanja. Drugo, mora se istaći da predlog izmena Krivičnog zakonika, koji je usvojen na Ekspertskom sastanku održanom u Beogradu 25. septembra 2020, ne bi suštinski ništa promenio, jer bi i dalje važila zabrana puštanja na uslovni otpust lica koja su osuđena na kaznu doživotnog zatvora, jer bi i dalje važila zabrana propisana u Zakonu o posebnim merama za sprečavanje vršenja krivičnih dela protiv polne slobode prema maloletnim licima, koji je, kada je reč o ovim krivičnim delima, lex specijalis u odnosu 
na Krivični zakonik. ${ }^{8}$ Treće, ideja da se "izvrše izmene i dopune Zakonika o krivičnom postupku s ciljem uvođenja novog - posebnog vanrednog pravnog leka - zahteva za vanredno ublažavanje kazne", je neprihvatljiva jer već postoji vanredni pravni lek koji ima upravo onu sadržinu koju predlaže prof. dr Vid Jakulin, a koji predlog je prihvaćen u okviru zaključaka Ekspertskog sastanka.

Svakako treba naglasiti i to da ideja koja polazi od teze da se učinioci krivičnih dela mogu popraviti, odnosno da bi ih trebalo pustiti na uslovni otpust iz "penoloških razloga", nije prihvatljiva kada je reč o licima koja su izvršila neko od krivičnih dela prema deci (licima mlađim od 14 godina), a pre svega krivična dela protiv polne slobode, jer ne postoji nikakva mogućnost da se to sa sigurnošću utvrdi. Naime, da li se neko ko je izvršio takvo krivično delo (toliko teško da mu je pravnosnažnom presudom izrečena kazna doživotnog zatvora), možemo znati tek kada se takvo lice nađe na slobodi, odnosno kada bude bilo ponovo u kontaktu sa decom. Njegovo eventualno "dobro" ponašanje u zatvoru nije pokazatelj da se popravio i u odnosu na decu, jer u zatvoru nije ni bilo u kontaktu sa decom. Dakle, tek po izlasku na uslovni otpust može se saznati da li se takav osuđenik zaista popravio, a to dalje znači da je za to saznanje potrebno rizikovati bezbednost dece, a nema dovoljno valjanih argumenata da se takav svojevrsni socijalni eksperiment (sam po sebi opasan po decu) dopusti ili prihvati. Drugim rečima, puštanjem takvog osuđenika na uslovni otpust, tek kada on bude u kontaktu sa decom, znaćemo da li se zaista popravio, pa ako nije, cena tog i takvog eksperimenta je život najmanje jednog deteta. To je svakako prevelika cena, koju niko ne bi smeo da pristane da plati.

\section{Zaključak}

Kada je reč o najnovijim rešenjima u Krivičnom zakoniku koja su uvedena u decembru 2019. nesporno je da gotovo svi noviteti izazivaju ozbiljnu polemiku u naučnoj, stručnoj ali i opštoj javnosti. Mišljenja su podeljena i ne postoji nijedno novo rešenje oko kojeg bi se svi saglasili da je dobro i da će doneti boljitak u bilo kojoj oblasti društvenog života. Često su mišljenja drastično različita, a ponekad i suprotna. Tako se postavlja i čitav niz ozbiljnih pitanja koja se odnose na kaznu doživotnog zatvora, počev od toga da li je ta kazna uopšte legitimna, preko toga kome i kada može da se izrekne, pa sve do toga kako će se ona izvršavati, i s tim u vezi, da li se lice osuđeno na kaznu doživotnog zatvora može uslovno otpustiti.

8 Predložene izmene bi se praktično odnosile samo na krivično delo ubistvo iz člana 114 stav 1 tačka 9 Krivičnog zakonika jer jedino to krivično delo nije obuhvaćeno Zakonom o posebnim merama za sprečavanje vršenja krivičnih dela protiv polne slobode prema maloletnim licima. 
Činjenica je da se može navesti mnogo prigovora novouvedenim rešenjima, kao i to da su nastala kao posledica penalnog populizma, koji podrazumeva pridobijanje glasača na izborima pooštravanjem propisanih kazni i zagovaranjem oštrije kaznene politike. Polazi se od ideje da je prosečan građanin sklon retributivnom odgovoru na zločin, zloupotrebljava se indukovani strah, koristi se manipulacija, a u svemu tome svoj doprinos pružaju mediji i nevladin sektor, pa uz jednostranost i nekompetentnost, koji su prisutni u ovom procesu, rezultati su prilično loši. Ljudi se ne osećaju ništa sigurnije, naprotiv, strah od zločina je sve veći a društvo troši sve više novca na finansiranje kaznenog mehanizma (Ignjatović, 2017: 28-29).

Međutim, mora se reći i to da postoji dosta neosnovanih prigovora i kritika. Često se u literaturi ističe da su najnovija rešenja u Krivičnom zakoniku loša, a da su loša zato što su, između ostalog, doneta pod pritiskom laičke javnosti (po pravilu se navodi inicijativa koju je podnela Fondacija Tijana Jurić), kojom se lako manipuliše, pogotovo kada je reč o krivičnim delima u kojima su žrtve deca, tim pre ako je reč o krivičnim delima protiv polne slobode. Tom prilikom se gubi iz vida činjenica da je svrha kažnjavanja ostvarivanje pravednosti i srazmernosti između učinjenog dela i težine krivične sankcije (član 42 tačka $4 \mathrm{KZ}$ ), a da svako, bez obzira na to da li jeste ili nije laik za krivično i krivično procesno pravo, jako dobro zna šta je pravedno i srazmerno kada je reč o ubistvu deteta, bremenite žene ili nekom krivičnom delu protiv polne slobode usled kojeg je došlo do smrti deteta. S tim u vezi, jako je važno da se naglasi neprihvatljivost nipodaštavanja stavova laičke javnosti i njihovih zahteva za srazmernost i pravednost (što je po njima kazna doživotnog zatvora bez prava na uslovni otpust), jer se presude ne donose u ime naučne i stručne javnosti, već u ime daleko brojnije populacije, tj. u ime naroda koji u ogromnoj većini čini upravo "laička javnost". Pošto se presuda donosi u ime tog i takvog naroda, onda se njegova želja ne sme i ne može ignorisati, naprotiv, mora se uvažiti.

Pokušaj ignorisanja želje laičke javnosti, koja čini ogromnu društvenu većinu u poređenju sa naučnom i stručnom javnošću, obesmišljava svrhu kažnjavanja koja se eksplicitno navodi u Krivičnom zakoniku kao izražavanje društvene osude za krivično delo (član 42 tačka 3). Upravo je laička javnost, kao najveći deo društva, pozvana da kroz kaznu izrazi društvenu osudu za konkretno krivično delo, pa se to mora uzeti u obzir, a u krajnjoj liniji i poštovati, čak i kada se ta javnost beskompromisno zalaže da se za pojedina krivična dela propiše, a po potrebi i izrekne kazna doživotnog zatvora, bez prava na uslovni otpust. Pri tome se mora imati u vidu da cilj kazne doživotnog zatvora bez prava na uslovni otpust, koji je propisan kod pojedinih krivičnih dela izmenama i dopunama iz decembra 2019. nije kazna sama za sebe, kako se to ponekad u literaturi predstavlja, nego 
zaštita dece. Taj cilj se svakako uklapa u svrhu kazne koju Krivični zakonik vidi, između ostalog, i u sprečavanju učinioca da čini krivična dela (član 42 tačka $1 \mathrm{KZ}$ ). S tim u vezi, treba imati u vidu i činjenicu, koju borci za prava osuđenih često zaboravljaju, da velika prava za izvršioca krivičnog dela, mogu biti, a vrlo često i jesu, velika nepravda za oštećene.

Kada je reč o predlogu izmena Krivičnog zakonika, koji je usvojen na Ekspertskom sastanku održanom u Beogradu 25. septembra 2020, a koji se svodi na uvođenje mogućnosti da se osuđenom na kaznu doživotnog zatvora odobri uslovni otpust, treba reći da se time ne bi suštinski ništa promenilo. Naime, tada bi i dalje važila zabrana puštanja na uslovni otpust lica koja su osuđena na kaznu doživotnog zatvora za određena krivična dela, odnosno i dalje bi važila zabrana propisana u Zakonu o posebnim merama za sprečavanje vršenja krivičnih dela protiv polne slobode prema maloletnim licima, koji je, kada je reč o ovim krivičnim delima, lex specijalis u odnosu na Krivični zakonik. Takođe, ideja usvojena na istom skupu, da se "izvrše izmene i dopune Zakonika o krivičnom postupku s ciljem uvođenja novog - posebnog vanrednog pravnog leka - zahteva za vanredno ublažavanje kazne", koji bi omogućio licima osuđenim na kaznu doživotnog zatvora da se eventualno puste na ulovni otpust, nije prihvatljiv, jer već postoji vanredni pravni lek, zahtev za ponavljanje krivičnog postupka (član 473 stav 1 tačka 6 ZKP), koji ima upravo takvu sadržinu.

$\mathrm{Na}$ ovom mestu treba reći i to da ideja koja polazi od teze da se učinioci krivičnih dela mogu popraviti, odnosno da bi ih trebalo pustiti na uslovni otpust iz "penoloških razloga", nije prihvatljiva kada je reč o licima koja su izvršila neko od krivičnih dela prema deci (licima mlađim od 14 godina), a pre svega krivična dela protiv polne slobode, jer ne postoji nikakva mogućnost da se to sa sigurnošću utvrdi. Naime, da li se neko ko je izvršio takvo krivično delo (toliko teško da mu je pravnosnažnom presudom izrečena doživotna kazna zatvora), možemo znati tek kada se takvo lice nađe na slobodi, odnosno kada bude bilo ponovo u kontaktu sa decom. Njegovo eventualno "dobro" ponašanje u zatvoru nije pokazatelj da se popravio i u odnosu na decu, jer u zatvoru nije ni bilo u kontaktu sa decom. Dakle, tek po izlasku na uslovni otpust može se saznati da li se takav osuđenik zaista popravio, a to dalje znači da je za to saznanje potrebno rizikovati bezbednost dece, a nema dovoljno valjanih argumenata da se takav svojevrsni socijalni eksperiment (sam po sebi opasan po decu) dopusti ili prihvati. Drugim rečima, puštanjem takvog osuđenika na uslovni otpust, tek kada on ponovo bude u kontaktu sa decom, znaćemo da li se zaista popravio, pa ako nije, cena tog i takvog eksperimenta je život najmanje jednog deteta. To je svakako prevelika cena, koju niko ne bi smeo da pristane da plati. 


\section{Literatura:}

- Dragojlović, J., Bingulac, N. (2019) Penologija između teorije i prakse. Novi Sad: Pravni fakultet za privredu i pravosuđe u Novom Sadu Univerziteta Privredna akademija u Novom Sadu.

- Đokić, I. (2013) Reforma kazne zatvora u krivičnom zakonodavstvu Republike Srbije - kazna zatvora u dugom trajanju ili doživotni zatvor? U: Evropske integracije i kazneno zakonodavstvo (poglavlje 23 - norma, praksa i mere harmonizacije), (str. 222-235). Zlatibor: Srpsko udruženje za krivičnopravnu teoriju i praksu i "Intermex" - Beograd.

- Ignjatović, Đ. (2000) Kriminologija. Beograd: Nomos.

- Ignjatović, Đ. (2017) Kazneni populizam. U: Kaznena reakcija u Srbiji VII deo, (str. 11-32). Beograd: Univerzitet u Beogradu - Pravni fakultet.

- Stevanović, Z. (2016) Uslovni otpust u Srbiji: progresivna ili regresivna rešenja. U: Međunarodni naučni tematski skup: Krivične i prekršajne sankcije $i$ mere: izricanje, izvršenje i uslovni otpust, (str. 427-438). Palić: Institut za kriminološka i sociološka istraživanja.

- Stojanović, Z. (2010) Krivično pravo opšti deo. Beograd: Pravna knjiga.

- Stojanović, Z. (2020) Komentar Krivičnog zakonika. Beograd: Službeni glasnik.

- Stojanović, Z., Škulić, M., Delibašić, V. (2018) Osnovi krivičnog prava, Krivično materijalno pravo, Knjiga I. Beograd: Službeni glasnik.

- Škulić, M. (2016) Uslovni otpust sa stanovišta krivičnog materijalnog i krivičnog procesnog prava. U: Međunarodni naučni tematski skup: Krivične i prekršajne sankcije i mere: izricanje, izvršenje i uslovni otpust, (str. 363-385). Palić: Institut za kriminološka i sociološka istraživanja. 


\section{LIFE IMPRISONMENT WITHOUT THE RIGHT TO PAROLE}

The introductory part of the paper indicates dilemmas regarding life imprisonment punishment. Further it defines the concept of punishment and determines the purpose of punishment, stating the essential characteristics of life imprisonment punishment. The life imprisonment punishment for criminal offenses in which conditional release is not possible has been taken under special consideration, indicating the legislator's omissions, and offering suggestion, so that the observed omissions could be corrected. The legal institute of conditional release, the European Convention for the Protection of Human Rights and Fundamental Freedoms, in the context of life imprisonment punishment, were discussed, followed by a critical review of the conclusions of the Expert Meeting held in Belgrade on September 25, 2020. An explanation has been given as to why it is not necessary to change the existing solution in our criminal legislation; with notice that even if the position derived from these conclusions should be accepted, that the existing legal solution ought to be changed, proposed implementation would not be acceptable, because the intent (which the author of this paper does not advocate for) would not be achieved by the proposals from that conclusions, as it is emphasized in this paper. Furthermore, the purpose of this paper is to find plausible arguments for the existing solution in our criminal legislation, meaning that for certain criminal offenses or the most serious forms of heinous crimes, offenders can be sentenced to life imprisonment without the right to parole. In addition, the objective is to specify that the conclusions of the Expert Meeting which was held in Belgrade on September 25, 2020, and especially the proposals attained from those conclusions are not admissible in relation to our criminal law.

Key words: sentence, life imprisonment, parole, human rights, criminal law. 